\title{
Socio-economic conditions for formation of an ecological and recreational cluster in the Rostov region and its development potential
}

\author{
Lyudmila Kazmina $^{1 *}$, Vadim Makarenko ${ }^{1}$, Valeria Provotorina ${ }^{1}$, and Elena Shevchenko ${ }^{1}$ \\ ${ }^{1}$ Don State Technical University, Gagarina Sq., 1, Rostov-on-Don, 344000, Russia
}

\begin{abstract}
The article is concerned with basic concepts related to development of an ecological-excursion cluster in the Rostov region. The socio-economic conditions of its formation are described. The research base on which the research related to the study of touristic clusters is found is reviewed. It also gives grounds for the possibility of functioning of the ecological and recreational cluster, defines its functions and importance for the development of inbound and domestic tourism, the economy and the social sphere of the region. The zoning of the territory of the Rostov region according to the prevailing types of ecological and recreational clusters is proposed and the specifics of their activities and the development of types of tourism are indicated.
\end{abstract}

\section{Introduction}

An effective tool for development of socio-economic systems in the sphere of tourism is implementation of a cluster approach that provides harmonization of private and public interests, diversification of risks and improvement of regional potential use.

The clustering process is coherent giving a number of management decisions related to the specifics of the industry, participants, location, capacity, and a number of other indicators. Therefore, it is necessary to develop an algorithm to cluster the regional territory and manage development of economic zones on the basis of a systematic approach and with consideration of all factors, which have an effect on this process. A sound cluster policy in the sphere of tourism development boosts its competitiveness and innovativeness.

Development of clusters is largely determined by the state of environment, some of the elements of which are socio-economic factors. This dependence is typical for all types of clusters and for touristic ones too.

The ecological and recreational cluster is a form of a touristic cluster, a system of interconnected natural resources, tourist enterprises, excursion routes, ecological paths, transport networks, accommodation facilities, catering establishments, tourist information centers and government bodies located on a certain territory.

Formation of the ecological and recreational cluster occurs under certain socioeconomic conditions, which include the degree of economic development of the region, the density of the transport network, population of the territory, the level of income of the

* Corresponding author: kafedra_tiig@mail.ru 
population, which allows maintaining and increasing the demand for ecological touristic products.

Functioning of ecological and recreational clusters can become a driver for sustainable development of the territory and a growth area for the tourism industry, economy and social sphere of the region.

The purpose of the article is to analyze the socio-economic conditions for formation and functioning of the ecological and recreational cluster of the Rostov region and to determine the prospects for its development.

Main tasks of the research:

- analysis of the research base in the context of development of touristic clusters;

- description of socio-economic conditions for formation of the ecological and recreational cluster in the Rostov region

- zoning according to promising types of ecological clusters.

\section{Materials and methods}

Formation of touristic and recreational regional clusters in the sphere of tourism becomes relevant more than ever. Clusters of this kind can become a driver for development of the regional economy. Due to the multiplier effect, it is possible to develop construction, transport, communications, trade, public catering and others. The cluster approach in the sphere of regional tourism is relevant largely due to the focus of state policy on that front. For example, the Concept of the Federal Target Program "Development of domestic and inbound tourism in the Russian Federation" for 2019-2025 defines "integrated development of touristic and supporting infrastructure of touristic clusters for priority types of tourism" as one of the priority tasks of tourism development. Touristic and recreational clusters can have various specific orientations. Sports, water and other types of clusters successfully exist in Russia. The most promising clusters are ecological tourist and recreational ones. This is explained by the great resource potential in this area and the demand for ecological tourism.

International best practices in touristic clustering of the territory are presented in the papers of such authors as Juan B.Duarte-Duarte Leonardo, H.Talero-Sarmiento, Diana C.Rodríguez-Padilla, 2021 [1]. Social, economic and spatial aspects of clustering are given in the papers of Marta Dereka, Edyta Woźniakb, Sylwia Kulczyka, 2019 and used in the course of conceptual developement of this article [2].

A review of the papers related to the Russian practice of clustering the territory according to touristic and recreational criteria refers to Kazmina, V.S. Makarenko, V.V. Provotorina, T.N. Grigorenko, Petrenko, A. 2021 [3, 4].

This study takes the opinions of scientists on such issues as general impact of domestic tourism on the regional economy, Nguyen Phuc Canh, Su Dinh Thanh, Peng Yu, Jinhe Zhang, Yaru Wang, ChangWang, Hongmei Zhang, $2020[5,6]$, and other areas of the tourism industry, e.g. carriers, Kan Wai Hong Tsui, 2017 [7] into acount.

Conceptual development of the present study was supported by opinions of Paula Remoaldo, Jaime Serra, Noémi Marujo Juliana Alves, Alexandra Gonçalves, Sónia Cabeça, Nancy Duxbury, 2020, relating to study of reasons to visit natural territories including rural areas, 2020 [8].

The ecological and recreational cluster is definitely based on ecological tourism that is inextricably linked to the concept of sustainable development of tourism. Therefore, scholary views of Robin Nunkoo, Haywantee Ramkissoon, Tsung Hung Lee, Fen-Hauh Jan, Jui-Tu Liu were also used in this article, 2020 [9, 10]. Theoretical and methodological approaches to sustainable development of tourism are presented in the papers of Dušan Ristić, Danijela Vukoičić, Miroljub Milinčić, 2019, [11, 12]. These papers define a need to 
establish strengths and weaknesses, as well as opportunities and threats related to tourism development in protected natural areas (nature reserves, wildlife areas, national parks), as tourism may have both positive and negative impact on territories.

Sustainable development of tourism is subject to development of a certain type of tourism, which is non-environment-damaging. Some scientists, such as Jing huiLi Yang Bai, Juha M.Alatalo, 2020, emphasize an intimate connection between tourism in ecological areas and near popular natural sites and environmental degradation [13]. At the same time, a need for a well-reasoned policy in the course of planning tourism in natural areas is underlined. Rights and opportunities of local tourism participants and their expected impact on the environment play an important role in development of ecological and recreational clusters in the context of sustainable development of tourism. This claim is present in the paper of Naser Shafieisabet, Saeideh Haratifard, 2020 [14]. Sustainable development of tourism in protected natural areas requires effective management including creation of ecological and recreational clusters. This approach is presented in the paper of Fernando Martin Y.Roxas, John Paolo R.Rivera, Eylla Laire M. Gutierrez 2020 [15].

It was found that outdoor recreational resources are of great importance for development of ecological tourism. In this regard, the paper of the Norwegian scientists K. Fossgard, P. Fredman should be noted [16]. In the present study, the authors used recommendations regarding technologies and algorithms of domestic tourism development in ecological areas with due regard to their geographical location and seasonal differences, Xiaojian Zhang, Limin Yu, Minjuan Wang, Wanlin Gao, 2018 [17]. Planning of tourism in protected natural areas (nature reserves, national parks) is of considerable importance. The experience of Italy, Serbia, Zambia, Cuba is taken into consideration [18, 19, 20].

Aspects of the territory under study from the perspective of tourism development, including ecological, are presented in the papers of some Russian authors, such as Kazmina, L., Ekinil, G., Shevchenko E., Makarenko, V., Provotorina, V. [21, 22].

Successful functioning of the ecological and recreational cluster requires specialists competent in this field. Therefore, importance of tourism education in the Rostov region is noted. It is described in the paper [23].

Thus, a review of scientific papers concerned with ecological and recreational clustering of the territory and ecological tourism makes it possible to provide an insight on this issue and to conduct a study.

The research methodology is based on the application of the following mwthods:

- comparative analysis, used to compare natural resources of districts of the Rostov region;

- descriptive analysis, implemented in the course of description of socio-economic conditions for formation of the ecological and recreational cluster;

- zoning of the territory, used in the course of identifying of main types of ecological clusters;

- prospective analysis, applied for identifying promising types of ecological clusters in various territories of the Rostov region.

\section{Results}

The clustering approach, traditionally used in the context of the industrial-production sphere of territorial development, has over time expanded the boundaries of its scientific application and covered a number of other territorially organized spheres including tourism. At the same time, the regional component began to prevail in studies, taking into account the specifics of touristic and recreational resources of the territories.

The starting point for using the clustering approach to the tourism sector was the article of A.Y. Alexandrova, who outlined the main conceptual apparatus of this approach, the 
structure of a touristic cluster, its system elements, etc. In the mentioned article, a cluster was understood as "a special form of territorial organization (self-organization) of production in the context of the market economy" [24].

The tourist cluster is not just a combination of tourism objects in a certain territory, but systemically interconnected elements, such as touristic infrastructure, accommodation facilities, catering establishments, places of interest, ecological paths, tourist information centers and others. At the same time, natural components are most fully represented in such a cluster form as ecological and recreational.

Ecological tourism is traditionally implemented in areas that are poorly affected by economic activity; therefore, the main objects of its development are, among other issues, specially protected natural areas. Accordingly, the ecological and recreational cluster will be a combination of interconnected ecological tourism objects in a certain territory - natural tourist resources, ecological paths, transport routes, accommodation facilities, ecological educational centers, museums, facilities for ecological festivals, etc.

In the paper of O.E. Afanasyev and A.V. Afanasyeva, there are three formclusters of ecotourism subject to its priority types in a particular territory. These are cognitive and educational types, recreational, cognitive and scientific ones [25]. The above mentioned classification shows that ecological tourism can also perform related functions - cognitive, educational, and scientific, etc. under condition of basic nature-oriented orientation. Nevertheless, formation and functioning of the cluster should be fundamentally based on ecological principles - reasonable coexistence of people and nature, preservation and multiplication of natural resources, limited human-induced (including touristic) impact.

Formation of the regional ecological and recreational touristic cluster aims at creation of a growth area and increased competitiveness of the regional economy by maintaining and developing the competitive advantages of the tourism sector, as well as at development of a comprehensive international product and providing consumers with domestic and inbound tourism services.

There is a need to constantly develop the existing ecological and recreational cluster, to make new ecological paths, to design landscapes with the purpose of aesthetics enhancement and performing a contemplative and creative function (this is important for such forms of ecological tourism as birdwatching). Thus, the activities of the cluster will be continuously improved and moved in the direction of sustainable development of tourism, economy and social sphere of the region.

In the Rostov region, certain socio-economic conditions have developed for formation of the ecological and recreational cluster. The factors contributing to creation of the cluster and its effective functioning include:

- availability of the unique outdoor recreational resource base;

- advantageous economical and geographical location (contact of the region with the center of Russia, the Urals, the North Caucasus and the South Caucasus);

- well-developed transport infrastructure enabling arrangement of inbound (including foreign tourists) and domestic tourism through the use of advanced infrastructure of federal railroads and highways, sea and river ports, Platov International Airport;

- defined legal framework;

- full range of proposed touristic services ready to be provided in the territory of the region;

- availability of zones good for development of ecological tourism, specially protected natural areas in the Rostov region;

- expertise in organization and holding of nature-oriented newsworthy events, such as Glorified Steppe Festival, Don River Festival, etc. in the region;

- high academic potential for staff training in the sphere of ecological tourism. 
However, a number of factors restraining formation of the ecological-recreational cluster should be noted:

- underdevelopment of tourist infrastructure in rural administrative districts of the region, in particular facilities of accommodation, catering and entertainment;

- lack of regional tour operators in the field of ecological tourism;

- poorly presented range of multi-day ecological touristic products;

- uncultivated public image of the Rostov region as a center for ecological tourism both in the Russian and international markets;

- absence of a unified cadastre of natural recreational touristic resources of the region.

The components of the cluster are a part of the sphere of management, infrastructure, tourist facilities, transport, hospitality industry, food, information (Fig. 1). Each element must also be improved according to changes in the internal and external environment, existing innovative technologies, dynamics of demand and ecological situation.

Structure of the ecological and recreational cluster can become a reference model for other types of touristic clusters. This conclusion is based on the fact that functioning of various types of tourism - educational, rural, food, ethnic - requires availability of the same elements of management, formation, and organization of a touristic product. Therefore, such clusters can be developed in the Rostov region on the basis of the proposed scheme in the future.

\section{Discussion}

Despite the general structure, ecological and recreational clusters differ in their content. This difference is determined by existing ecosystems, prevailing landscape, implemented forms of ecological tourism, etc.

In the territory of the Rostov region, several zones can be distinguished by particular features of formation of prospective ecological and recreational clusters. Distinguishing of 4 zones seems to be appropriate: South west, east, south, and north (Table 1).

Table 1. Zoning of prospective ecological and recreational clusters in the Rostov region.

\begin{tabular}{|c|c|c|c|}
\hline Zone name & Municipal formation & Cluster type & Cluster name \\
\hline North & $\begin{array}{c}\text { the Sholokhovsky and } \\
\text { Bokovskaya districts }\end{array}$ & Landscape (steppe) & the Don Steppe \\
\hline the Azov, Aksay, \\
$\begin{array}{c}\text { Bagaevskaya, } \\
\text { Neklinovsky, } \\
\text { Myasnikovsky, Ust- } \\
\text { Donetsky districts }\end{array}$ & Water (river) & $\begin{array}{c}\text { 2. the Manych } \\
\text { Valley }\end{array}$ \\
\hline East & $\begin{array}{c}\text { Remontan } \\
\text { the Orlovsky, } \\
\text { Volgodonsk districts }\end{array}$ & $\begin{array}{c}\text { Ornithological } \\
\text { (birdwatching), } \\
\text { Plant, } \\
\text { Water }\end{array}$ & $\begin{array}{c}\text { 1. the Rostov } \\
\text { Reserve }\end{array}$ \\
\hline West & the Belaya Kalitva district & $\begin{array}{c}\text { Forest (floodplain } \\
\text { forests) }\end{array}$ & Black Gully \\
\hline
\end{tabular}

Zoning of ecological and recreational clusters of the Rostov region by types will make it possible to develop a rifle approach to planning of their activity on the one hand, and to vary the forms of ecological tourism on the other hand. Forming of each cluster should be based on development of its main touristic resources accompanied with environmental planning. Therefore, for classification by types of ecological-recreational clusters, basic forms of landscapes are selected, on the basis of which the priority directions of ecological tourism will be determined. 
Location of ecological clusters near urbanized territories of the region will provide local residents with an opportunity to have outdoor leisure activity and recreation. Moreover, formation of ecological thinking, love for nature, and awareness of consequences of anthropogenic pressure on the environment will be top-priority.

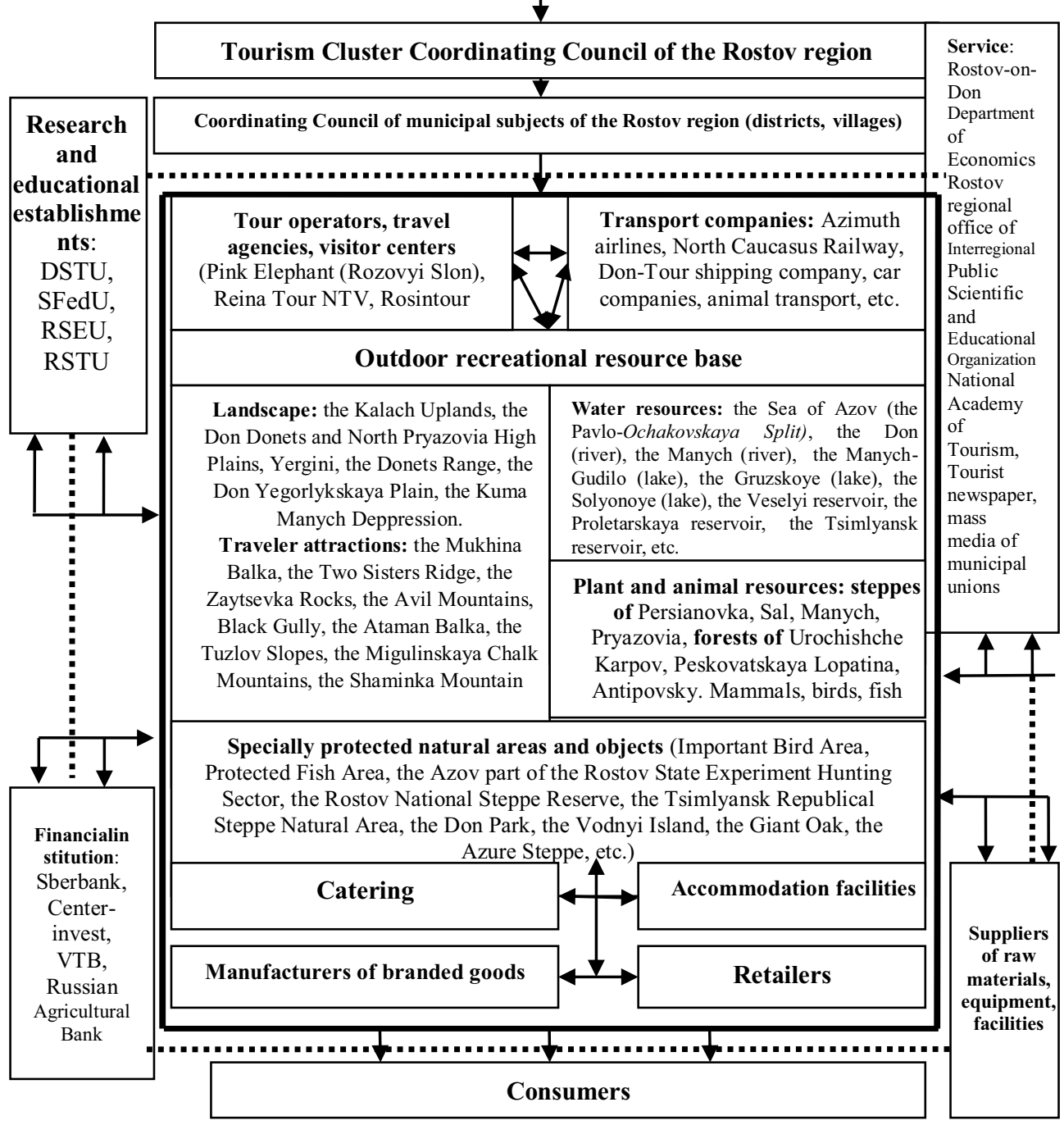

Fig. 1. Structure of the ecological and recreational cluster of the Rostov region.

It should be noted that formation and development of the ecological and recreational cluster, promoting a strong growth of tourist flow to the Don region, will provide:

- building an image of the region as a center for ecological tourism, contributing to the growth of the region's economy;

- integration of the territory into the system of the Russian and world markets of ecological tourism and development of international cooperation in this area;

- development of a comprehensive touristic international product;

- significant contribution of tourism to solving employment problems in the Rostov region, not only in quantitative terms through generating employment due to a rise in small and medium enterprises, but also in structural context; 
- modernization and expansion of tourism infrastructure by attracting extra-budgetary funding sources in the course of investment distribution;

- increased demand for world-class tourist staffing by way of retraining or proficiency enhancement in the field of ecological tourism and for a system of continuing professional tourism education;

- increased innovativeness of the ecological tourism sector (formation of new ecological paths, enhancement of the forms of arranging excursions) and tertiary sector;

- implementation of environmental planning, particularly using the proceeds of tourist and excursion services;

- increased amount of tax revenues from enterprises of ecological tourism and related industries;

- growth of the material well-being of local citizens of the Rostov region.

In the case of appropriate development, the ecological and recreational cluster can become a basis for sustainable development of tourism in the Rostov region, as well as facilitate additional flows of inbound tourists to the region, and support development of domestic tourism.

\section{Conclusions}

Following the conducted research of analysis of socio-economic conditions formation of the ecological-recreational cluster and prospects of its development, a number of conclusions can be made.

1. The Rostov region has required socio-economic conditions for formation and further development of the ecological and recreational cluster, such as: a combination of outdoor recreational resources, a favorable economical and geographical location, a well-developed transport network, a large number of potential consumers of ecological touristic products, etc.

2. Segregated structure of the ecological and recreational cluster, presented in the form of a diagram, can become a model for formation and development of clusters related to other types of tourism, such as educational, rural, food, ethnic.

3. Zoning of the territories of the Rostov region by types of ecological and recreational clusters made it possible to identify four main zones and several types of clusters. The most outstanding of them are landscape, water, ornithological, plant, and forest. The specified areas are distinguished by a combination of natural resources and traveler attractions.

4. Clustering policy including implementation of a toolbox of state support aimed at formation and development of clusters in the Rostov region is a promising trend for increasing the competitiveness of the region. Formation of the touristic cluster will result in building of a contemporary competitive tourist market in the region.

\section{References}

1. J. B. Duarte-Duarte, L. H. Talero-Sarmiento, D. C. Rodríguez-Padilla, Research Article, 7 (4), e06655 (2020), https://doi.org/10.1016/j.heliyon.2021.e06655

2. M. Derek, E. Woźniak, S. Kulczyk, Tourism Management, 75, 509-521 (2019), https://doi.org/10.1016/j.tourman.2019.06.014

3. L. N. Kazmina, V. S. Makarenko, V. V. Provotorina, T. N. Grigorenko, International Journal of Economics and Business Administration, 7, 510-520 (2019), doi: $10.35808 /$ ijeba/297

4. V. Provotorina, L. Kazmina, A. Petrenko, V. Makarenko, Lecture Notes in Civil Engineering, 130, 20-32 Springer, Singapore (2021) 
5. N. P. Canh, S. D. Thanh, Annals of Tourism Research, 85, 103063, (2020), doi.org/10.1016/j.annals.2020.103063

6. P. Yu, J. Zhang, Y. Wang, C. Wang, H. Zhang, Science of The Total Environment, 748, 141099 (2020), doi.org/10.1016/j.scitotenv.2020.141099

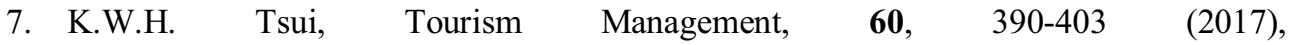
https://doi.org/10.1016/j.tourman.2016.10.013

8. P. Remoaldo, J. Serra, N. M. J. Alves, A. Gonçalves, S. Cabeça, N. Duxbury, Tourism Management Perspectives, 36, 100746 (2020), doi.org/10.1016/j.tmp.2020.100746

9. R. Nunkoo, H. Ramkissoon, Tourism Management, 33 (4), 1002-1003 (2012), https://doi.org/10.1016/j.tourman.2011.10.003

10. T. H. Lee, F.-H. Jan, J.-T. Liu, Ecological Indicators, 125, 10759 (2020), https://doi.org/10.1016/j.ecolind.2021.107596

11. D. Ristić, D. Vukoičić, M. Milinčić, Land Use Policy, 89, 104231 (2019), doi.org/10.1016/j.landusepol.2019.104231

12. Z. M. Navarro-Martínez, C. M. Crespo, L. Hernández-Fernández, et al., Ocean \& $\begin{array}{llll}\text { Coastal Management, } & 105188 & \text { (2020), }\end{array}$ https://doi.org/10.1016/j.ocecoaman.2020.105188

13. J. huiLi, Y. Bai, J. M.Alatalo, Ecosystem Services, 42, 101081 (2020), doi.org/10.1016/j.ecoser.2020.101081

14. N. Shafieisabet, S. Haratifard, Journal of Hospitality and Tourism Management, 45, 486-498 (2020), https://doi.org/10.1016/j.jhtm.2020.10.007

15. S. Obradović, V. Stojanović, S. Kovačić, et al., Journal of Outdoor Recreation and Tourism, 35, 100384 (2021), https://doi.org/10.1016/j.jort.2021.100384

16. K. Fossgard, P. Fredman, Journal of Outdoor Recreation and Tourism, 28, 100219 (2019), https://doi.org/10.1016/j.jort.2019.04.001

17. X. Zhang, L. Yu, M. Wang, W. Gao, Pattern Recognition Letters, 31, 10024 (2018), doi.org/10.1016/j.patrec.2018.12.022

18. A. Buongiorno, M. Intini, Land Use Policy, 101, 105220 (2021), https://doi.org/10.1016/j.landusepol.2020.105220

19. M. D'Arco, L. L. Presti, V. Marino, G. Maggiore, Land Use Policy, 101, 105198 (2021), https://doi.org/10.1016/j.landusepol.2020.105198

20. A. Chidakel, B. Child, S. Muyengwa, Ecological Economics, 182, 106960 (2021), https://doi.org/10.1016/j.ecolecon.2021.106960

21. L. Kazmina, V. Makarenko, V. Provotorina, E. Shevchenko, E3S Web of Conferences, 175, $10001(2020)$

22. V. Provotorina, L. Kazmina, A. Petrenko, G. Ekinil, E3S Web of Conferences, 175, $10002(2020)$

23. L. Kazmina, V. Makarenko, V. Provotorina, E., Shevchenko, E3S Web of Conferences, 210, 12002 (2020), DOI: https://doi.org/10.1051/e3sconf/202021012002

24. A. Y. Aleksandrova, Contemporary Issues in Service and Tourism, 1, 51-61 (2007)

25. O. E. Afanasyev, and A.V. Afanasyeva, Contemporary Issues in Service and Tourism, $4-11(2017)$ 